AHMAD NAZRUL HAKIMI IBRAHIM, M.Sc. ${ }^{1}$

E-mail: nazrulhakimi@siswa.ukm.edu.my

MUHAMAD NAZRI BORHAN, Ph.D. ${ }^{1}$

(Corresponding author)

E-mail: mnazribborhan@ukm.edu.my

NUR IZZI MD. YUSOFF, Ph.D. ${ }^{1}$

E-mail: izzi@ukm.edu.my

AMIRUDDIN ISMAIL, Ph.D. ${ }^{1}$

E-mail: aismail@ukm.edu.my

${ }^{1}$ Department of Civil Engineering

Faculty of Engineering and Built Environment

Universiti Kebangsaan Malaysia

43600 UKM Bangi, Selangor, Malaysia
Human-Transport Interaction

Review

Submitted: 23 May 2019

Accepted: 19 Feb. 2020

\title{
RAIL-BASED PUBLIC TRANSPORT SERVICE QUALITY AND USER SATISFACTION - A LITERATURE REVIEW
}

\begin{abstract}
While rail-based public transport is clearly a more advanced and preferable alternative to driving and a way of overcoming traffic congestion and pollution problems, the rate of uptake for rail travel has remained stagnant as a result of various well-known issues such as that commuters either use a more reliable and comfortable alternative to get from $A$ to $B$ and/or that they are not satisfied with the quality of service provided. This study examined the factor of user satisfaction regarding rail-based public transport with the aim of discovering precisely what factors have a significant effect on the user satisfaction and uptake of rail travel. This was approached using both the Delphi approach and a thorough review of the current literature, focusing on a total of nine possible factors affecting passenger satisfaction with rail travel availability of service, accessibility of service, ticket or pass, punctuality, clarity of information, quality of customer service, comfort, safety, and image. Also discussed were 29 extra possible attributes and several measures that were implemented in various countries to increase the service quality. It was concluded that this review will provide valuable information for policymakers, researchers and service providers in terms of specifying the service factors most worth investigating if the quality of this crucial means of transport is to be raised.
\end{abstract}

\section{KEY WORDS}

public transport; railway; service quality; user satisfaction; literature review;

\section{INTRODUCTION}

In today's society, public transport plays a vital role both in urban and rural settings and most people are either directly or indirectly affected by the quality, availability and accessibility of public transport services. Many countries have prioritised developing good public rail services in order to cut down on car dependency. Indeed, it is now universally recognised that dependence on cars is a very negative development which has only led to traffic jams, environmental problems, noise, accidents and air contamination in most of the cities worldwide. [1]. One of the central steps in ensuring sustainability is, therefore, to provide good public transport systems which offer a high quality and affordable alternative for citizens and which will lead to a reduction in the use of private vehicles. Mouwen [2] argued that emissions by urban passenger transport could be reduced by up to $40 \%$ by 2050 if commuters switched to alternative means of transport, such as cycling, walking, or rail travel in cities. Also, Soehodho [3] confirmed that the number of traffic accidents would be reduced by providing cheap public transport which fulfilled the capacity needs of travellers.

Unfortunately, the investment and speedy development of public transport services by governments is not always accompanied by the eagerness 
to adopt such facilities. Van Lierop et al. [4] pointed out that in many parts of the world the use of public transport remains at a lower rate than the use of private vehicles. Masirin et al. [5] confirmed that this is the case in Kuala Lumpur, where the uptake of rail-based public transport is still low, in spite of huge investments over the past few decades. For Zulkifli et al. [6] the rate of rail-based ridership is also one of the most serious concerns in Asian literature, due to the factors such as travel costs [7-9], quality of service $[10,11]$, paucity of connections, long distances to and from the stations and home or workplace [12]. The habits are also recognised as significantly affecting the public choice to use public transport [13]. Habits, of course, are built when a particular action is routinely repeated with a certain amount of stability, resulting in beneficial outcomes. It is a regrettable and widely-recognised fact that populations are generally reluctant to change their habit of using private vehicles since they are faster and able to support a busy lifestyle by offering more privacy, flexibility, comfort, convenience, reliability, independence, $[14,15]$.

Given this situation, it is necessary, therefore, to develop new strategies to make rail transport more attractive in terms of its sustainability and to find ways to attract new users of public transport while retaining the existing ones $[16,17]$. The challenge is to offer a high-quality public service which fulfils passenger expectations, ensures their satisfaction and offers value for money. Passengers who are pleased with the provided rail system will not only be encouraged to continue using the service in the future but will be inclined to recommend the service to others [4]. It is, therefore, very important to investigate the user satisfaction with the quality of the rail-based public transport service in their area.

Generally, it could be said that it is crucial for policymakers and practitioners to identify and fully understand precisely which factors influence the passenger satisfaction with rail-based public transport prior to formulating comprehensive strategies for increasing the ridership [18]. In recognition of the swift development of rail-based public transport worldwide, it was essential for this study to thoroughly review the previous studies in order to gain a greater understanding of these satisfaction factors. This study was guided by the following two research questions: (1) What are the factors influencing the user satisfaction? (2) What are the recommended strategies for improving the user satisfaction and increasing the ridership? This paper benefits researchers and rail-based public transport service providers by identifying the service factors to be investigated when addressing the quality of any rail-based public transport service. Furthermore, this study identifies and discusses the key recommended strategies which need to be adopted if any real improvement in passenger satisfaction with rail services is going to take place.

The present review next presents its considered definition of service factors, followed by a discussion of the factors that affect passenger satisfaction with public rail transportation. The last section concludes by summarising the primary findings of the present review and provides recommendations for policies which would help improve the passenger satisfaction.

\section{DEFINING SERVICE FACTORS}

Even a brief review of the current literature on this topic reveals how different variables are employed to discuss the influences on passenger satisfaction with rail transport. This means that there were, in fact, two steps to selecting which definitive service factors would be employed in the current study: namely, the literature review and the Delphi approach. Based, therefore, on a thorough review of the literature, an initial index of themes and sub-themes was drawn up, with a total of nine themes selected. These were: availability of service, accessibility of service, ticket or pass, comfort, time, information, customer service, safety, and image. In addition, 34 sub-themes were selected from a thorough review of the literature, using the Delphi method for identifying the corresponding sub-themes for each theme, which would enable the evaluation of the level of importance for each theme and sub-theme. The Delphi method was adopted for this study because it would offer a deeper insight by requiring not just one but several rounds of questionnaires in an iterative process with experts. Also, the anonymity of the respondents through this method would ensure less bias and remove the possible effects of group pressure [19].

At the beginning of the Delphi process a survey was designed which would attempt to assess the opinions of specialists such as researchers and engineers on the nine themes and 34 sub-themes which were identified from the literature review. This questionnaire was comprised of two sections, the first of which matched the sub-themes with their relevant themes, while the second used a five-point Likert 
Ibrahim ANH, Borhan MN, Md. Yusoff NI, Ismail A. Rail-based Public Transport Service Quality and User Satisfaction...

Table 1 - Description of attributes

\begin{tabular}{|c|c|c|}
\hline Factor & Attribute & Description \\
\hline \multirow{4}{*}{ Availability of service } & Frequency & Number of trips per day; \\
\hline & Network coverage & Extension of the rail line for users to access other destination; \\
\hline & Operating hours & Operating hours of service; \\
\hline & Parking facility & Availability of parking facilities at railway stations; \\
\hline \multirow{2}{*}{ Accessibility of service } & Accessibility & $\begin{array}{l}\text { Availability of railway to accommodate as many users as possible and } \\
\text { ease of boarding and alighting the train; }\end{array}$ \\
\hline & Ease of transfer/ Distance & Simplest connection for users to another rail line/vehicle; \\
\hline \multirow{2}{*}{ Ticket/Pass } & Ticket price & Monetary cost of travel; \\
\hline & Type of tickets/ Pass & $\begin{array}{l}\text { Various types of tickets/passes such as student, infant and senior citizen } \\
\text { passes or daily, weekly or monthly passes; }\end{array}$ \\
\hline \multirow{2}{*}{ Information } & On-board information & $\begin{array}{l}\text { Up-to-date, precise and reliable information on board (such as route, } \\
\text { stop announcement, advertisement, operating hour, service interrup- } \\
\text { tion); }\end{array}$ \\
\hline & Information at stations & $\begin{array}{l}\text { Up-to-date, precise and reliable information is provided at stations } \\
\text { (such as price, route, stop announcement, advertisement, operating hour, } \\
\text { service interruption); }\end{array}$ \\
\hline \multirow{5}{*}{ Travel time } & Punctuality & Punctuality of train departure and arrival; \\
\hline & Access time & Time taken by user to access the railway station from origin; \\
\hline & Travel speed & Time spent in train to travel between specific points; \\
\hline & Waiting time & Length of waiting time before boarding the train; \\
\hline & Transfer time & Time taken by user to transfer to another rail line/vehicle; \\
\hline \multirow{2}{*}{ Customer service } & $\begin{array}{l}\text { Driver and } \\
\text { personnel behaviour }\end{array}$ & Attitude and courteousness of the drivers and personnel; \\
\hline & Customer service & $\begin{array}{l}\text { Effectiveness and swiftness when dealing with user's daily problems } \\
\text { such as ticket purchasing, auto-gate and ticket validation problem; }\end{array}$ \\
\hline \multirow{7}{*}{ Comfort } & Cleanliness & Level of cleanliness in trains and at the station; \\
\hline & Comfort & $\begin{array}{l}\text { Level of comfort during the journey in terms of driver handling, access } \\
\text { to seat, leg room on board, comfortable seating; }\end{array}$ \\
\hline & Seating capacity & Number of seats on a train; \\
\hline & Quality of vehicles & $\begin{array}{l}\text { Physical and mechanical condition of trains, including frequency of } \\
\text { breakdown; }\end{array}$ \\
\hline & Noise & Noise level in trains or at stations; \\
\hline & Temperature & $\begin{array}{l}\text { Temperature in the train, including air conditioning, heating and venti- } \\
\text { lation; }\end{array}$ \\
\hline & Waiting condition & Quality of waiting environment at stations; \\
\hline \multirow{2}{*}{ Safety } & On board safety & Level of safety from crime and accidents in the train; \\
\hline & Safety at station & $\begin{array}{l}\text { Level of safety from crime and accidents at the station. Safety at station } \\
\text { includes protected walkway, speed limit sign, warning sign, signage; }\end{array}$ \\
\hline \multirow{2}{*}{ Image } & Image & $\begin{array}{l}\text { Users' perception of rail-based public transport or their involvement } \\
\text { with the service; }\end{array}$ \\
\hline & Eco-friendly & Rail-based public transport is greener than for private vehicles. \\
\hline
\end{tabular}


scale to rank the level of importance of each of the themes and sub-themes, ranging from "not important" through to "very important".

The Delphi process finally offered 14 (out of 14) themes and 29 (out of 34) sub-themes which would serve as the defining service factors for this study which influence passenger satisfaction with public rail transportation. Interestingly, five of the subthemes, being ticket-selling network, staff commitment, ergonomics, physical assistance and customer interface were removed from the list due to their mean score being below three out of five and, therefore, not relevant in the judgement of the Delphi experts [20]. The themes (factors), Sub-themes (attributes) and description of all attributes are presented in Table 1.

\section{SERVICE FACTORS THAT INFLUENCE RAIL-BASED USER SATISFACTION}

The service factors identified in previous literature and reviewed in this paper are represented in Table 2. The check $(\sqrt{ })$ symbol denotes a significantly important factor influencing the public rail transportation user satisfaction, while the absence of ' $\sqrt{ }$ ' means that it is not statistically significant or was not used in this study. The ' $\sqrt{ }$ ' symbol is found throughout Table 2 as different studies investigating the different service factors which various researchers deemed important were based on a variety of factors linked to the case studies, such as geographic or demographic factors. For example, Das et al. [21] concluded that 13 factors were statistically significant for the satisfaction of monorail users in Kuala Lumpur, while Yanık et al. [32] argued for only 11 major factors in their study of the metro passengers of Istanbul.

The following section discusses, in turn, each of the nine selected factors with their attributes for this study: availability of service, accessibility of service, ticket or pass, information, travel time, customer service, comfort, safety, and image. It should be noted that this discussion is not confined only to the selected papers appearing in Table 2 but refers also to the literature for support and discussion.

\subsection{Availability of service}

Availability of service refers to the service provided by the public rail authorities. The analysis of the findings of previous studies shows that availability of service comprises several factors, including service provision, frequency, network coverage, and parking facilities.

The frequency of service is, of course, a key factor for passengers in the availability of public rail transportation and has an impact on passenger satisfaction [29, 30]. In fact, Mouwen [2], Tyrinopoulos \& Antoniou [23] and Shen et al. [28] argued that public transport users perceive frequency as the largest determinant of whether they would be willing to depend less on motor vehicles and adopt public transport [36]. This finding is supported by Khalid et al. [25] who concluded that the switch to using commuter trains (KTM commuter) is always reliant on the service frequency provided by the service provider (KTMB). As would be expected, higher frequency positively affects public transport efficiency, makes a trip more predictable and shortens the perceived time, whereas a low-frequency service results in problems like congestion in rush hours, extended waiting periods, overloading of trains and overcrowding at stations. Naturally, such factors cause users to feel dissatisfied with the service on offer and, consequently, less inclined to adopt the service. A low-frequency public rail transportation service, unsurprisingly, results in low ridership [37, 38]. The uptake of public rail transportation in many developed countries, such as the United Kingdom, South Korea, Japan and the United States is high because of better frequency compared to that in many developing countries. For instance, the frequency of the underground service in South Korea is between 3 to 5 minutes, compared to 15 minutes during peak hours and 30 minutes during off-peak hours for commuter trains in Kuala Lumpur, Malaysia [25]. It is widely agreed that this is the primary reason for the low rate of ridership of commuter trains in Kuala Lumpur, Malaysia, a situation which has resulted in a very high number of user complaints. In contrast, the subway in Seoul, South Korea recorded a total of 2.619 billion riderships in 2013 [39]. Mouwen [2] and Githui et al. [40] argued that passengers who have no complaint about frequency of service are more likely to be satisfied with the overall service.

An equally important factor influencing the overall satisfaction is the operating hours [31]. Also, the network coverage has an impact on overall passenger satisfaction [31, 41]. A literature review carried out for this study shows that any 


\begin{tabular}{|c|c|c|c|c|c|c|c|c|c|c|c|c|c|c|c|c|c|c|c|}
\hline 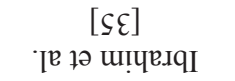 & & & $>$ & & $>$ & $>>$ & $>$ & & & & $>$ & $>$ & $>$ & & & $>$ & $>>$ & & $>$ \\
\hline 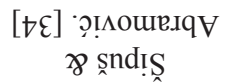 & $>$ & & & $>$ & $>>$ & & & $>$ & & & & & & & & & $>>$ & & \\
\hline 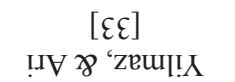 & & & & $>>$ & $>>$ & $>>$ & $>$ & $>$ & & & $>$ & $>7=$ & & & $>>$ & & & $>$ & \\
\hline 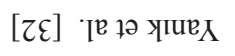 & & & & $>$ & & & $>$ & $>>$ & $>$ & $>$ & & $>>$ & $>>$ & & $?$ & & $>>$ & & \\
\hline 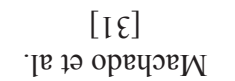 & $>$ & $>>$ & & $>>$ & $>$ & $>>$ & $>>$ & $>>>$ & $>$ & & $>$ & $>>$ & $>$ & $>$ & 7 & & $>>$ & & \\
\hline 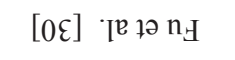 & $>$ & $>>$ & & $>>$ & $>>$ & $>>$ & $>>$ & $>>$ & & $>$ & & $>=$ & $>>$ & $>$ & & & $>>$ & & \\
\hline 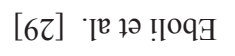 & $>$ & $>>$ & & $>>$ & $>>$ & $>>$ & $>>$ & $>>$ & & $>$ & & $>=$ & $>>$ & $>$ & & & $>>$ & & \\
\hline [8Z] ' '• & $>$ & 7 & & & $>>$ & $>>$ & $>>$ & $>>$ & & $>$ & & $>>$ & $>$ & & $>$ & $>$ & $>>$ & & \\
\hline 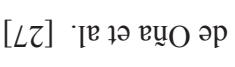 & $>$ & $>>$ & $>$ & $>$ & & $>>$ & $>>$ & $>>$ & $>$ & $>$ & & $>=$ & $>>$ & & $>$ & & $>>$ & & $>$ \\
\hline 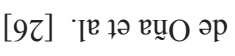 & $>$ & & $>$ & & $>$ & $>>$ & $>$ & & & $>$ & & $>=$ & $>$ & $>$ & & & $>$ & & \\
\hline 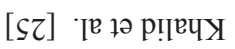 & $>$ & & & & & & $>$ & & $>$ & & & & & & & & & & \\
\hline 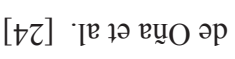 & $>$ & & $>$ & & $>$ & $>>$ & $>$ & & & $>$ & & $>=$ & $>$ & $>$ & & & $>$ & & \\
\hline 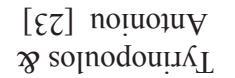 & $>$ & $>$ & & $>>$ & $>>$ & $>>$ & $>$ & & $>$ & 7 & & $>$ & & $>$ & & $>$ & $>$ & & \\
\hline [zz] и!әңsu!ə & $>$ & & $>>$ & $>b$ & & $>$ & $>$ & & $>$ & $>$ & & $>=$ & $>>$ & $>$ & & $>>$ & & & \\
\hline 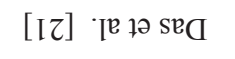 & & $>$ & $>$ & $>$ & $>$ & $>$ & $>$ & & & & & $>>$ & $>>$ & & & $>$ & $>$ & & $>$ \\
\hline [乙] иәмпоџ & $>$ & & & $>$ & $>$ & $>>$ & $>>$ & $>>$ & & $>$ & & $>=$ & $>>$ & & $>$ & & $>>$ & & \\
\hline 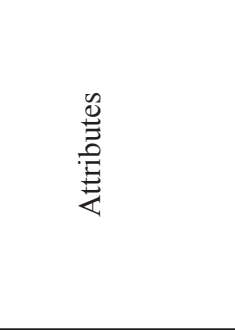 & 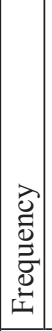 & 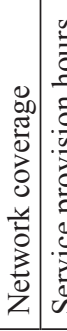 & 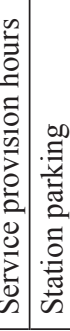 & 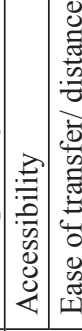 & 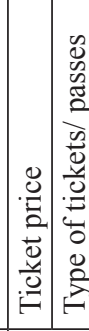 & 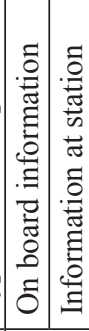 & 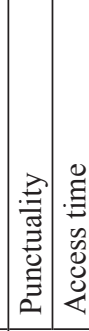 & 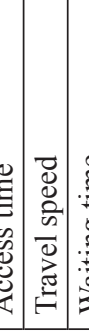 & 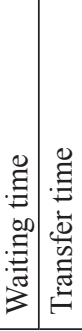 & 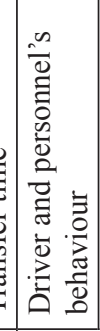 & 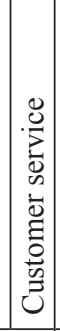 & 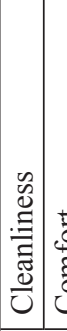 & 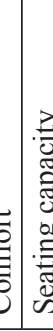 & 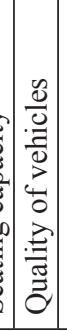 & \begin{tabular}{|c|c|c} 
& \\
& \\
& \\
0
\end{tabular} & 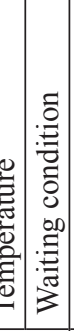 & 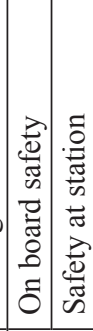 & 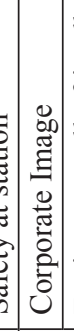 & 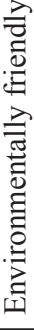 \\
\hline 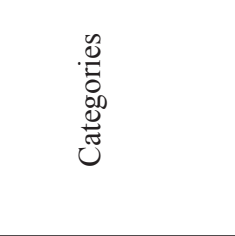 & & 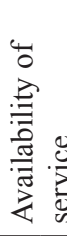 & & 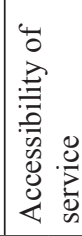 & 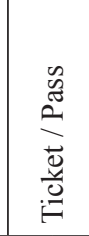 & 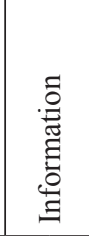 & & 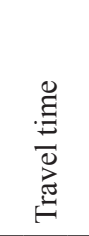 & & 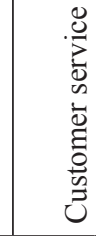 & & & & $\begin{array}{l}\text { :ै } \\
\text { है } \\
\text { 己े }\end{array}$ & & & 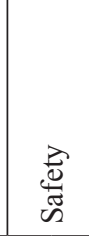 & $\begin{array}{l}\text { g. } \\
\text { gू } \\
\text { g }\end{array}$ & \\
\hline
\end{tabular}


well-performing public rail transportation system will have a wide network coverage which allows passengers to travel from A to B at their favoured time with little transfer time [22], access time [27], and waiting time [23, 25], as well as ease of transfer [29, 31]. Another convenience consideration for public rail transportation users is whether or not they will find parking facilities at the rail stations (or park and ride facilities). Certainly, this is also an important motivator for adopting the rail travel [26].

In short, the public perception of a high-quality public rail service largely depends on the frequency of the service, in addition to generous operating hours, wide network coverage and available parking facilities. These are crucial considerations for passenger satisfaction, retaining current passengers and attracting new users.

\subsection{Accessibility of service}

Accessibility is also a key influencer on public satisfaction among both 'captive' and 'choice' public rail transportation users [27, 33]. Brons et al. [42] examined the importance of the trip to the station to the overall passenger satisfaction and concluded that, based on the regression analysis, passenger satisfaction with access to their nearest station is an important factor in overall satisfaction with the service. According to Hine \& Scott [43] and Krygsman et al. [44], accessibility to a rail station influences passenger satisfaction and motivates the users to choose rail-based transport as a travel alternative. Several studies have investigated the users' access journeys to the railway station and confirmed the importance of this factor, such as Rietveld [45], Polom et al. [16] and Givoni \& Rietveld [46]. Another factor which influences the overall satisfaction within this theme is ease of transfer which, according to passenger's transfer experience means a smooth transfer between vehicles. For Weinstein [22], the ease of transfer includes the length of the queue at the exit gate and the presence of serviced and reliable escalators and lifts. Also, Tyrinopoulos \& Antoniou [23] confirmed that the distance of transfer influences the overall satisfaction of railbased public transport users. In fact, various studies have supported the view that the ease of transfer is correlated with the overall satisfaction [47].
To summarise this section, the ease of access to stations and the ease of transfer are also important factors for the satisfaction of passengers using railbased public transport.

\subsection{Ticket or pass}

Another factor which can have a considerable impact on the satisfaction of rail-based public transport users is ticketing. Public sector rail transportation authorities have to focus on two essential aspects of ticketing in an attempt to persuade the public to use their service: ticket prices and types of tickets. Travel price is, of course, one of the primary determinants of satisfaction with any public transport service $[26,30]$. Generally, a lower ticket price contributes to enhancing passenger satisfaction and increasing rail travel uptake. De Witte et al. [36] also pointed out, however, that the users are willing to pay more according to the purpose of their trip and comfort during their trip. In view of this, Tyrinopoulos \& Antoniou [23] recommended that public rail transportation operators offer several types of tickets and passes with different price structures to cater to the diverse needs of the users. Githui et al. [40] and Redman et al. [15] also supported a range of tickets and passes such as seasonal passes (daily, weekly, monthly), discounted ticket prices for certain categories of users (e.g. students, children, persons with disabilities, or senior citizens), transferrable passes and automated ticketing. Matas [48] demonstrated that the availability of different prices and types of tickets improved passenger satisfaction with the public transport service in Madrid and resulted in a $50 \%$ increase in ridership over a period of five years.

In summary, it is clear that ticket pricing and the availability of a wide range of ticket types and passes are also vital for improving passenger satisfaction with the rail services.

\subsection{Information}

Up-to-date, reliable, and accurate information is also essential for ensuring the overall passenger satisfaction with public rail transportation. Many studies have shown that the information provided on trains and at the stations is statistically significant in influencing the public rail transportation user satisfaction. Machado-Leóna et al. [31] included in this information stops on a line, operating hours, prices, and service interruptions. Clear and updated 
information on train schedules and routes is, naturally, important for improving the passenger satisfaction and attracting new users of rail-based transport [4]. For the literature, there is widespread agreement that this area needs to improve radically, and that rail-based public transport operators and other relevant authorities should seriously consider making information on train schedules more readily accessible, displaying ticket prices clearly at the station and making announcements in a clear manner using major world languages. Burkhardt [49] and Krizek \& El-Geneidy [50] argued that the two proven effective ways of delivering information on the train and at the station are via displays and announcements. In line with this, the particular information discussed in this paper is limited to on-board information and those provided at the stations by public rail transportation operators.

It is clear then that providing information to passengers in these two ways is a contribution to their overall satisfaction with the service. A recommendation for future studies in line with the advances in technology is for transport researchers to investigate the advantages of using more advanced methods of disseminating information afforded by that technology, such as mobile applications.

\subsection{Travel time}

Travel time is also, naturally, correlated with passenger satisfaction levels, since people are generally more motivated to choose the mode of transport that is able to take them from their point of origin to their destination in the shortest duration. It goes without saying that rail-based public transport is a more attractive option during peak hours compared to other modes of public transport (e.g. bus) since commuters will not get stuck in traffic. With this given advantage, it is essential for railbased public transport providers to consider improving their time efficiency with the aim of enhancing passenger satisfaction and attracting more potential users [51]. Based on a review of previous studies, punctuality or on-time performance is the most important factor in ensuring overall passenger satisfaction with public rail transportation [30, 31]. Unsurprisingly, many studies have confirmed that the punctuality of a public rail transportation service is able to enhance passenger satisfaction levels and that passengers who are satisfied with the punctuality will probably be satisfied with the overall service. This has been demonstrated by Das et al. [21],
Githui et al. [40], Mouwen [2], and Weinstein [22]. Consequently, the authors of this paper recommend that the service operators take steps to ensure the punctuality of drivers and that trains are in good operating condition, considering the major effect that these factors have on the on-time performance of the public rail transportation. Importantly, service operators should also publicise the preventive actions they have taken to prevent delays in the arrival and departure of their trains.

The speed of the train service has also been shown to correlate with the satisfaction levels as mentioned by Mouwen [2], de Oña et al. [27], Eboli et al. [29], and Shen et al. [28]. Naturally, commuters are motivated to use public rail transportation during peak hours instead of road-based public transport in order to arrive at their target destination on time. The speed of trains could be increased to improve passenger satisfaction, thereby ensuring their future patronage whilst at the same time attracting potential users. According to the US Federal Transit Administration, as cited in Redman et al. [15], an improvement in the rail service which reduced the commuting time by 15 minutes from New York station to the outlying areas resulted in a $24.5 \%$ increase in ridership within a one-year period. In addition, in the case of buses, Pucher et al. [52] pointed out that the implementation of priority bus lanes, which increased the average bus speed from $11 \mathrm{~km} / \mathrm{h}$ to $22 \mathrm{~km} / \mathrm{h}$, was able to attract as many as 700,000 new users per day.

Of course, speed is indirectly proportional to the waiting time. With respect to public rail transportation, higher speed of vehicles allows for a higher frequency service to be provided, thereby reducing the user waiting time at the stations. The analysis of previous studies indicates that the waiting time is one of the major determinants of passenger satisfaction [27, 31, 32]. A long waiting time due to an unreliable service has a very detrimental effect on the passenger satisfaction and can cause passengers to decide not to use the service in the future. For example, Khalid et al. [25] highlighted the fact that the users of commuter trains in Malaysia were not satisfied with their commuter train service due to the long waiting times. That study reported that the longest waiting time for a user before being able to board a train was 2 hours and 30 minutes. This was often compounded by not being able to board the first train during peak hours due to overcrowding and low service speed, even though they had arrived 
at the station early to wait for the arrival of the first train. This finding was supported by the evidence at the Los Angeles Metro Orange Line BRT system, where, according to Pucher et al. [52], the orange line that was designed to minimise the waiting times resulted in an over two-fold improvement in ridership compared to other metro lines.

It should be made clear that for this study, the waiting time refers only to the unexpected waiting time due to improper service. The expected waiting time (where the user has been notified of service delay through, e.g. smartphone applications before arriving at the station) could change the user's waiting experience but have no adverse effect on the satisfaction with public rail transportation. More indepth studies need to be carried out to investigate the relationship between the expected waiting experience and the passenger's satisfaction level with the public rail transportation.

Other factors, such as access time, have also been shown to influence the rail-based passenger satisfaction $[27,28]$. This is consistent with the findings of other studies, such as Eboli et al. [29], Fu et al. [30], Machado-Leona et al. [31] and Yilmaz and Ari [33]. The analysis of these studies revealed that the access time is considered as important as the travel speed.

It is clear, then, based on the studies discussed here, that time is considered by passengers to be of major importance in affecting their satisfaction with their rail service. Rail-based public transport service providers are, therefore, recommended to prioritise punctuality, travel speed, waiting times, transfer times and access times in their efforts to improve the passenger satisfaction. Shorter and more punctual travel times will, undoubtedly, influence both passenger satisfaction and loyalty to public rail transportation facilities.

\subsection{Customer service}

The quality of any interactions between public rail transportation users and the operators or management team of the rail system is likely to affect the overall level of satisfaction [22, 40]. One vital aspect of such interactions is the professionalism and courteousness of drivers and personnel and the manner in which the service providers handle any complaints lodged by users as well as routine problems faced by users. The present study defines this interaction as customer service.
Customer service is another essential factor which determines the level of satisfaction of railbased public transport users and dissatisfaction naturally occurs if poor customer service is perceived. Tyrinopoulos \& Antoniou [23] discovered that the personnel attitude and behaviour (not including drivers) is one of the most important satisfaction attributes based on the ordered logit model. Additionally, Mouwen [2] pointed out that personnel/ driver behaviour is the most important element which users view as the determinant of their overall satisfaction in addition to other factors such as punctuality, travel speed, service performance, and cleanliness of the vehicles. This finding has been supported by several studies [27-30], including a study by Machado-Leóna et al. [31] which investigated the service quality of Algiers' railway transit system and found, as expected, that effective customer service enhances the overall passenger satisfaction. Various strategies for improving customer service were recommended in these studies for ensuring the user satisfaction with the public rail transportation, such as improving customer service counters and departments, enhancing the effectiveness and speed of dealing with problems and complaints, and providing the most up-to-date, precise, and reliable information at stations. While such recommendations are nothing new, Geetika [53] made the important point that personnel behaviour (railway staff, porters, and parking attendants) is the second most important determinant influencing passenger satisfaction.

It is clear that the perceived quality of customer service has an important impact on the overall passenger satisfaction, demanding more in-depth study. Improving the quality of their customer services is an effective and economic way of improving the overall public perception of rail-based public transport operators. Van Lierop et al. [4], among many others, argued that fast, effective, and responsive customer service when dealing with problems would certainly improve the passenger satisfaction levels.

\subsection{Comfort}

Many transport studies have addressed comfort features such as the standard of vehicles and stations. For this study, the comfort theme comprises cleanliness, user comfort, seating capacity, quality of vehicles, noise, temperature, and waiting conditions. Studies show that the two most important determinants influencing passenger satisfaction 
are cleanliness and comfort $[21,24]$. According to Weinstein [22], for example, the attributes with the strongest correlation to cleanliness and comfort are train cleanliness, comfortable seats and noise level in trains. These factors, naturally, influence the satisfaction level of public rail transportation users and numerous studies confirm that cleanliness and comfort have a statistically significant relationship with the satisfaction level [31-33]. Greece, Athens, Begg \& Langley [54], basing their study on ordered logit model analysis, found that vehicle cleanliness was the most important factor influencing satisfaction. This is supported by the findings of a study on passenger perception of railway services in Northern Italy carried out by Eboli \& Mazzulla [55], which concluded that cleanliness and comfort, together with regularity, punctuality and frequency of runs have the strongest positive effect on service quality, information and satisfaction level. Regarding cleanliness, it is clear that service providers everywhere need to bear the cost of providing more waste bins and recycle bins to promote recycling campaigns. Additionally, some policies have to be better enforced, such as no-smoking policies, no eating and drinking policies and, as mentioned, waste recycling policies to improve cleanliness in trains and at stations.

Lee et al. [56] noted that the level of comfort in carriages means, for passengers, comfortable seats on trains. Additionally, Weinstein [22], Das et al. [21], Mouwen [2], and de Oña et al. [27] found that seating capacity also plays an important role in determining the satisfaction levels. Other factors that are closely related to comfort and user satisfaction are the quality of the carriages [30,31], noise levels [33] and on-board temperature [28].

In addition, the waiting conditions, of course, contribute to passenger satisfaction with public rail transportation. It should be noted, however, that although many studies have included waiting conditions as a factor in passenger satisfaction with the public transport, only three studies have shown that the waiting conditions have a strong influence on the levels of satisfaction [21-23]. User perception of waiting conditions seems to be more important in the studies carried out in the non-European countries, for example, the United States [22] and Malaysia [21]. It goes without saying, then, that the user comfort is also one of the important elements that need to be the focus of public rail transportation service providers everywhere.

\subsection{Safety}

There are two aspects to safety: visible and non-visible. Visible safety refers to, for example, safety from traffic accidents and crime, while non-visible safety refers to safety due to psychological factors. Based on a review of the literature, two safety indices were further discussed in this study, namely safety while on-board rail carriages and safety at stations.

Safety is a crucial determiner of overall satisfaction levels [29], whether related to on-board safety $[21,26]$ or safety at stations [2, 23]. Moreover, safety with regard to feeling safe from traffic accidents [27] and crime [30] also, naturally, influences the satisfaction level of rail-based public transport users. While Eboli et al. [29] showed that safety during a journey affects overall satisfaction, Mouwen [2] contended that safety at stops is a key determinant of satisfaction. This is in agreement with the findings of other studies reviewed for the current paper, such as Shen et al. [28], Eboli et al. [29] and Fu et al. [30]. Eboli \& Mazzulla [55] in which safety and security were identified by the users as being important for their satisfaction with the public rail transportation sector, in general. Safety-related issues at stations and on trains have certainly attracted the attention of many researchers worldwide, both in the developed and in the developing countries.

It could be said, then, that the safety issue, whether on trains or at stations, is another aspect which concerns public rail transportation users. To deal with such valid concerns, the rail service operators are wise to adopt preventive measures which make both rail carriages and train stations safer places for passengers, such as installing a sufficient number of CCTVs and posting police officers on trains in an effort to prevent pickpocketing, sexual harassment, etc.

\subsection{Corporate image}

The corporate image of rail-based public transport services and authorities is constructed primarily on the service quality. Put simply, the better the corporate image, the higher the tendency of the public to use the service provided by the public rail transportation operators [57-59]. Corporate image can have a direct and positive effect on passenger satisfaction [33], a finding supported by Hsu et al. [57], Kuo \& Tang [59] and Chou \& Kim [58]. Presently, the public transport authorities persuade potential users to use their services via advertisements 
or mass media campaigns on either television, social media or in newspapers. According to Borhan et al. [60], mass media campaigns are able to significantly influence the behaviour and enhance trust between the customer and the producer, thereby motivating the customers to try the product. Mass media campaigns certainly have the potential to attract the users to adopt public rail transportation services, which indirectly increases the ridership and generates income for the service. Even though there is plenty of evidence that corporate image influences the passenger satisfaction, this factor is seldom included in the papers reviewed by the authors, with the exception of Yilmaz \& Ari [33]. Perhaps this factor might be included in any future investigations of passenger satisfaction, especially in the context of public rail transportation. Furthermore, environmental factors are also associated with the satisfaction level of public rail transportation users. This fact has been supported by the studies of Das et al. [21], de Oña et al. [27] and Ibrahim et al. [35]. For example, rail-based public transport users who are confident that traffic congestion and pollution can be reduced by taking public transport because of a positive corporate image campaign, might be more satisfied with the overall service. Having a modern, environmentally friendly and reputable image will enhance passenger satisfaction with the rail service and user willingness to adopt rail-based public transport services.

\section{CONCLUSION}

Focusing on public rail transportation passenger satisfaction and goals for improving this satisfaction, this study is a comprehensive review of the related literature. The research questions were: (1) What are the factors influencing user satisfaction? and (2) What are the recommended strategies for improving user satisfaction and increasing ridership? The factors which influence the user satisfaction with rail-based public transport and several measures which might improve passenger satisfaction were investigated. After a thorough review of the literature, nine factors were selected: availability of service, accessibility of service, ticket or pass, information, time, customer service, comfort, safety, and image. These were proven, in previous studies, to have a definite correlation with rail-based public transport passenger satisfaction.
It has been seen in this review that action is certainly needed in order to address the passenger satisfaction with public rail services and that this comes in the form of a variety of measures. It is strongly recommended that providers develop services which are efficient, physically accessible and whose capacity meets the needs of passengers. The services should also be clean, comfortable, affordable, trusted, and safe to those who wish to use them, while information on trains and at stations should be accurate and regularly updated. This study also emphasised the need for polite and courteous drivers and personnel who would exhibit good customer service, which could be achieved through proper repeated training courses.

In practical terms, the findings of this study might also aid researchers or service providers in better identification of the factors that influence the user satisfaction with rail-based public transport services. This study can also play an important role in forming a foundation for future studies of service quality and user satisfaction related to rail-based public transport.

\section{ACKNOWLEDGEMENT}

This research was funded by the Universiti Kebangsaan Malaysia (Grant Number: GUP-2019-015) and the Ministry of Higher Learning Malaysia (Grant Number: FRGS/1/2017/TK08/UKM/01/1).

\author{
AHMAD NAZRUL HAKIMI IBRAHIM, M.Sc. ${ }^{1}$ \\ E-mel: nazrulhakimi@siswa.ukm.edu.my \\ MUHAMAD NAZRI BORHAN, Ph.D. ${ }^{1}$ \\ E-mel: mnazri_borhan@ukm.edu.my \\ NUR IZZI MD. YUSOFF, Ph.D. ${ }^{1}$ \\ E-mel: izzi@ukm.edu.my \\ AMIRUDDIN ISMAIL, Ph.D. ${ }^{1}$ \\ E-mel: aismail@ukm.edu.my \\ 1 Jabatan Kejuruteraan Awam, \\ Fakulti Kejuruteraan dan Alam Bina, \\ Universiti Kebangsaan Malaysia, \\ 43600 UKM Bangi, Selangor, Malaysia
}

\section{KUALITI PERKHIDMATAN \\ PENGANGKUTAN AWAM BERASASKAN REL DAN KEPUASAN PENGGUNA: KAJIAN KEPUSTAKAAN}

\section{ABSTRAK}

Walaupun pengangkutan awam berasaskan rel adalah lebih maju dan menjadi alternatif yang lebih baik kepada pemanduan kenderaan persendirian, serta merupakan satu kaedah untuk mengurangkan kesesakan lalu lintas dan masalah pencemaran, kadar pengguna 
kereta api masih rendah disebabkan oleh pelbagai isu seperti pengguna menggunakan pengangkutan alternatif lain yang lebih di percayai dan selesa untuk perjalanan daripada A kepada B dan/atau mereka tidak berpuas hati dengan kualiti perkhidmatan yang disediakan. Kajian ini menyiasat faktor kepuasan pengguna terhadap pengangkutan awam berasaskan rel untuk mengetahui dengan lebih tepat faktor yang mempunyai kesan yang signifikan terhadap kepuasan pengguna dan penggunaan mod pengangkutan ini. Kajian yang menggunakan pendekatan Delphi dan kajian menyeluruh terhadap kesusasteraan terkini ini telah memberi tumpuan kepada sembilan faktor yang mungkin mempengaruhi kepuasan pengguna terhadap perjalanan kereta api; ketersediaan perkhidmatan, kebolehcapaian perkhidmatan, tiket atau pas, ketepatan masa, maklumat yang tepat, kualiti perkhidmatan pelanggan, keselesaan, keselamatan dan imej. Turut dibincangkan adalah 29 atribut yang berkemungkinan dapat meningkatkan kepuasan pengguna dan beberapa pendekatan yang telah dilaksanakan di pelbagai negara untuk meningkatkan tahap kualiti perkhidmatan. Sebagai kesimpulan, kajian ini akan dapat menyediakan maklumat yang berguna kepada penggubal dasar, penyelidik dan pembekal perkhidmatan dari segi menentukan faktor perkhidmatan yang paling penting untuk dikaji jika ingin meningkatkan kualiti perkhidmatan pengangkutan ini.

\section{KATA KUNCI}

pengangkutan awam; kereta api; kualiti perkhidmatan; kepuasan pengguna; kajian kepustakaan;

\section{REFERENCES}

[1] Borhan MN, Ibrahim ANH, Syamsunur D, Rahmat RA. Why Public Bus is a Less Attractive Mode of Transport: A Case Study of Putrajaya, Malaysia. Period Polytech Transp Eng. 2019;47(1): 82-90. Available from: https:// pp.bme.hu/tr/article/view/9228

[2] Mouwen A. Drivers of customer satisfaction with public transport services. Transp Res Part A Policy Pract. 2015;78: 1-20. Available from: doi:10.1016/ j.tra.2015.05.005

[3] Soehodho S. Public transportation development and traffic accident prevention in Indonesia. IATSS Res. 2017;40(2): 76-80. Available from: doi:10.1016/j.iatssr. 2016.05.001

[4] Van Lierop D, Badami MG, El-Geneidy AM. What influences satisfaction and loyalty in public transport? A review of the literature. Transp Rev. 2018;38(1): 52-72.

[5] Masirin MIM, Salin AM, Zainorabidin A, Martin D, Samsuddin N. Review on Malaysian Rail Transit Operation and Management System: Issues and Solution in Integration. IOP Conf Ser Mater Sci Eng. 2017;226(1): 1-7.

[6] Mohamad Zulkifli SNA, Kadar Hamsa AA, Noor NM, Ibrahim M. Evaluation of land use density, diversity and ridership of Rail Based Public Transportation System. Transp Res Procedia. 2017;25(2017): 5266-81.
Available from: http://linkinghub.elsevier.com/retrieve/ pii/S2352146518300577

[7] Cools M, Fabbro Y, Bellemans T. Free public transport: A socio-cognitive analysis. Transp Res Part A Policy Pract. 2016;86: 96-107. Available from: doi:10.1016/ j.tra.2016.02.010

[8] Borndörfer R, Karbstein M, Pfetsch ME. Models for fare planning in public transport. Discret Appl Math. 2012;160(18): 2591-605.

[9] Torok A. Statistical Analysis of Transport Performance: Case Study for Hungary. Procedia Eng. 2017;187: 722-5. Available from: doi:10.1016/j.proeng.2017.04.446

[10] Abenoza RF, Cats O, Susilo YO. Travel satisfaction with public transport: Determinants, user classes, regional disparities and their evolution. Transp Res Part A Policy Pract. 2017;95: 64-84. Available from: doi:10.1016/ j.tra.2016.11.011

[11] Farooq MS, Salam M, Fayolle A, Jaafar N, Ayupp K. Impact of service quality on customer satisfaction in Malaysia airlines: A PLS-SEM approach. J Air Transp Manag. Elsevier Ltd; 2018;67 (January): 169-80. Available from: doi:10.1016/j.jairtraman.2017.12.008

[12] Chowdhury S. Users' willingness to ride an integrated public-transport service: A literature review. Transp Policy. 2016;48: 183-95.

[13] Thøgersen J. Promoting public transport as a subscription service: Effects of a free month travel card. Transp Policy. 2009;16(6): 335-43. Available from: doi:10.1016/j. tranpol.2009.10.008

[14] STEG L. Can Public Transport Compete With the Private Car? IATSS Res. 2003;27(2): 27-35. Available from: http://linkinghub.elsevier.com/retrieve/pii/ S0386111214601412

[15] Redman L, Friman M, Tommy G, Hartig T. Quality attributes of public transport that attract car users - A research review. Transp Policy. 2013;25: 119-27.

[16] Polom M, Tarkowski M, Puzdrakiewicz K. Urban Transformation in the Context of Rail Transport Development: The Case of a Newly Built Railway Line in Gdansk (Poland). $J$ Adv Transp. 2018;2018: 15 p.

[17] Borhan MN, Ibrahim ANH, Miskeen MAA. Extending the theory of planned behaviour to predict the intention to take the new high-speed rail for intercity travel in Libya: Assessment of the influence of novelty seeking, trust and external influence. Transp Res Part A Policy Pract. 2019;130: 373-84.

[18] Fellesson M, Friman M. Service Supply and Customer Satisfaction in Public Transportation: The Quality Paradox. J Public Transp. 2009;12(4):13. Available from: http://www.nctr.usf.edu/jpt/pdf/JPT12-4Friman.pdf

[19] Kamaruzzaman SN, Lou ECW, Wood R, Che-ani AI. Developing weighting system for refurbishment building assessment scheme in Malaysia through analytic hierarchy process (AHP) approach. Energy Policy. 2018;112: 28090. Available from: doi:10.1016/j.enpol.2017.10.023

[20] Alyami SH, Rezgui Y, Kwan A. Developing sustainable building assessment scheme for Saudi Arabia: Delphi consultation approach. Renew Sustain Energy Rev. 2013;27: 43-54.

[21] Das AM, Ladin MA, Ismail A, Rahmat ROK. Consumers satisfaction of public transport monorail user in Kuala 
Lumpur. J Eng Sci Technol. 2013;8(3): 272-83.

[22] Weinstein A. Customer Satisfaction Among Transit Riders: How Customers Rank the Relative Importance of Various Service Attributes. Transp Res Rec. 2000;1735(1): 123-32.

[23] Tyrinopoulos Y, Antoniou C. Public transit user satisfaction: Variability and policy implications. Transp Policy. 2008;15(4): 260-72.

[24] De Oña R, Eboli L, Mazzulla G. Key factors affecting rail service quality in the Northern Italy: A decision tree approach. Transport. 2014;29(1): 75-83. Available from: doi:10.3846/16484142.2014.898216

[25] Khalid UA, Bachok S, Osman MM, Ibrahim M. User Perceptions of Rail Public Transport Services in Kuala Lumpur, Malaysia: KTM Komuter. Procedia - Soc Behav Sci. 2014;153: 566-73. Available from: http://linkinghub. elsevier.com/retrieve/pii/S1877042814055311

[26] De Oña J, de Oña R, Eboli L, Mazzulla G. Heterogeneity in Perceptions of Service Quality among Groups of Railway Passengers. Int J Sustain Transp. 2015;9(8): 612-26.

[27] De Oña J, de Oña R, Eboli L, Forciniti C, Mazzulla G. Transit passengers' behavioural intentions: the influence of service quality and customer satisfaction. Transp A Transp Sci. 2016;12(5): 385-412.

[28] Shen W, Xiao W, Wang X. Passenger satisfaction evaluation model for Urban rail transit: A structural equation modeling based on partial least squares. Transp Policy. 2016;46(1): 20-31.

[29] Eboli L, Fu Y, Mazzulla G. Multilevel Comprehensive Evaluation of the Railway Service Quality. Procedia Eng. 2016;137: 21-30.

[30] Fu Y, Eboli L, Mazzulla G, Zhang Y. Railway service quality in northern Italy: A multilevel synthetic assessment. Adv Mech Eng. 2017;9(3): 1-12.

[31] Machado-Leóna JL, de Oñaa R, Baounib T, de Oñaa J. Railway transit services in Algiers: Priority improvement actions based on users perceptions. Transp Policy. 2017;53: 175-85.

[32] Yanık S, Aktas E, Topcu YI. Traveler satisfaction in rapid rail systems: The case of Istanbul metro. Int J Sustain Transp. 2017;11(9): 642-58.

[33] Yilmaz V, Ari E. The effects of service quality, image, and customer satisfaction on customer complaints and loyalty in high-speed rail service in Turkey: A proposal of the structural equation model. Transp A Transp Sci. 2017;13(1): 67-90.

[34] Šipuš D, Abramović B. The Possibility of Using Public Transport In Rural Area. In: Procedia Engineering. 2017;192: 788-93. Available from: doi:10.1016/j.proeng.2017.06.136

[35] Ibrahim ANH, Borhan MN, Zakaria NA, Zainal SK. Effectiveness of Commuter Rail Service Toward Passenger's Satisfaction: A Case Study from Kuala Lumpur, Malaysia. Int J Eng Technol. 2019;8(1-2): 50-5.

[36] De Witte A, Hollevoet J, Dobruszkes F, Hubert M, Macharis C. Linking modal choice to motility: A comprehensive review. Transp Res Part A Policy Pract. 2013;49: 329-41.

[37] De Vasconcellos EA. Urban change, mobility and transport in São Paulo: Three decades, three cities. Transp Policy. 2005;12(2): 91-104.
[38] Szczuraszek T, Chmielewski J. Sustainable transport development passenger transport demand in Poland. In: MATEC Web of Conferences; 2018.

[39] Han J, Kwon S bark, Chun C. Indoor environment and passengers' comfort in subway stations in Seoul. Build Environ. 2016;104: 221-31. Available from: doi:10.1016/j.buildenv.2016.05.008

[40] Githui JN, Okamura T, Nakamura F. The Structure of Users' Satisfaction on Urban Public Transport Service in Developing Country: The Case of Nairobi. J East Asia Soc Transp Stud. 2010;8: 1288-300.

[41] Saif MA, Zefreh MM, Torok A. Public Transport Accessibility: A Literature Review. Period Polytech Transp Eng. 2018;46(3): 1-8.

[42] Brons M, Givoni M, Rietveld P. Access to railway stations and its potential in increasing rail use. Transp Res Part A Policy Pract. 2009;43(2): 136-49.

[43] Hine J, Scott J. Seamless, accessible travel: Users' views of the public transport journey and interchange. Transp Policy. 2000;7(3): 217-26.

[44] Krygsman S, Dijst M, Arentze T. Multimodal public transport: An analysis of travel time elements and the interconnectivity ratio. Transp Policy. 2004;11(3): 265-75.

[45] Rietveld P. The accessibility of railway stations: The role of the bicycle in The Netherlands. Transp Res Part D Transp Environ. 2000;5(1): 71-5.

[46] Givoni M, Rietveld P. The access journey to the railway station and its role in passengers' satisfaction with rail travel. Transp Policy. 2007;14(5): 357-65.

[47] Susilo YO, Cats O. Exploring key determinants of travel satisfaction for multi-modal trips by different traveler groups. Transp Res Part A Policy Pract. 2014;67: 36680. Available from: doi:10.1016/j.tra.2014.08.002

[48] Matas A. Demand and revenue implications of an integrated public transport policy: The case of Madrid. Transp Rev. 2004;24(2): 195-217.

[49] Burkhardt JE. Critical measures of transit service quality in the eyes of older travelers. Transp Res Rec. 2003;(1835): 84-92. Available from: http://www.scopus. com/inward/record.url?eid=2-s2.0-1542346277\&partnerID=tZOtx3y 1

[50] Krizek K, El-Geneidy A. Segmenting preferences and habits of transit users and non-users. J Public Transp. 2007;10(3): 71-94. Available from: http://nctr.usf.edu/ jpt/pdf/JPT 10-3 Krizek.pdf

[51] Oszter V. Transport policies in Hungary - historical background and current practice for national and regional level. Eur Transp Res Rev. 2017;9(20): 1-14.

[52] Pucher J, Park H, Kim M, Song J. Public transport reforms in Seoul: Innovations motivated by funding crisis. J Public Transp. 2005; 41-62. Available from: http://citeseerx.ist.psu.edu/viewdoc/download?doi= 10.1.1.170.9559\&rep $=$ rep1\&type $=$ pdf

[53] Geetika SN. Determinants of Customer Satisfaction on Service Quality: A Study of Railway Platforms in India. J Public Transp. 2010;13(1): 97-113.

[54] Begg DJ, Langley JD. Identifying predictors of persistent non-alcohol or drug-related risky driving behaviours among a cohort of young adults. Accid Anal Prev. 2004;36(6): 1067-71.

[55] Eboli L, Mazzulla G. Structural Equation Modelling 
for Analysing Passengers' Perceptions about Railway Services. Procedia - Soc Behav Sci. 2012;54: 96-106. Available from: http://linkinghub.elsevier.com/retrieve/ pii/S1877042812041912

[56] Lee JH, Jin BS, Ji Y. Developmentw of a Structural Equation Model for ride comfort of the Korean highspeed railway. Int J Ind Ergon. 2009;39(1): 7-14.

[57] Hsu SH, Chen WH, Hsueh JT. Application of customer satisfaction study to derive customer knowledge. Total Qual Manag Bus Excell. 2006;17(4): 439-54.

[58] Chou JS, Kim C. A structural equation analysis of the QSL relationship with passenger riding experience on high speed rail: An empirical study of Taiwan and Korea. Expert Syst Appl. 2009;36(3): 6945-55.

[59] Kuo C-W, Tang M-L. Relationship among service quality, corporate image, customer satisfaction and behaviroal intention for the elderly in high speed rail service. $J A d v$ Transp. 2013;47: 512-25. Available from: http://onlinelibrary.wiley.com/doi/10.1002/atr.144/full

[60] Borhan MN, Ibrahim ANH, Miskeen MAA, Rahmat RAOK, Alhodairi AM. Predicting car drivers' intention to use low cost airlines for intercity travel in Libya. $J$ Air Transp Manag. 2017;65: 88-98. Available from: doi:10.1016/j.jairtraman.2017.09.004 